\section{Epidemiological characteristics of Brazilian spotted fever in Minas Gerais State, Brazil, 2000-2008}

\author{
Aspectos epidemiológicos dos casos de febre \\ maculosa brasileira ocorridos em Minas Gerais, \\ Brasil, 2000 a 2008
}

\author{
Frederico Figueiredo Amâncio 1 \\ Vânia Dutra Amorim 1 \\ Talita Leal Chamone 1 \\ Mariana Gontijo de Brito 1 \\ Simone Berger Calic 2 \\ Anamaria Cordeiro Leite 1 \\ Gabriela Lobato Fraga 1 \\ Marcela Lencine Ferraz 1
}

\section{Introduction}

Brazilian spotted fever is the most common rickettsiosis in Brazil, most prevalent in the States of São Paulo and Minas Gerais. The aim of this study was to describe the epidemiological characteristics of Brazilian spotted fever in Minas Gerais from 2000 to 2008. Of the 132 cases of Brazilian spotted fever, 53 patients died, representing a case-fatality rate of $40.2 \%$. Males predominated, with 78.8\% of confirmed cases, and median age was 26.5 years. Absence of rash was associated with increased risk of death $(p=0.005)$. Greater Metropolitan Belo Horizonte, Rio Doce Valley, and Zona da Mata accounted for 70.6\% of the cases, which occurred mainly from May to November. There was an increase in the number of cases, which could suggest an expansion of the disease, but probably resulted from an increase in the health system's diagnostic capacity and sensitivity. Despite this improvement, the casefatality rate remains high and with no apparent tendency to decrease, thus indicating the need for improved prevention and patient care.

Rocky Mountain Spotted Fever; Rickettsiaceae Infections; Diagnosis
Brazilian spotted fever (BSF) is the most common rickettsiosis in Brazil, with the largest number of confirmed cases in the States of São Paulo and Minas Gerais. The disease was described for the first time in Brazil in 1929 in São Paulo, followed soon after by Minas Gerais and Rio de Janeiro. At present, there have been reported cases in all the States of the Southeast and South regions, in addition to scattered cases in other regions of the country 1. In Minas Gerais the disease has been reported mainly in the Jequitinhonha, Mucuri, and Rio Doce valleys 1,2,3,4,5,6.

Considered an acute febrile infectious disease, BSF is caused by the bacteria Rickettsia rickettsii and transmitted by tick bites. The disease shows high case-fatality and is difficult to diagnose, especially in its initial phase, since it presents unspecific symptoms 7 . Serological diagnosis is only possible when there are antibodies that appear around the 7 th to 10th day after the onset of symptoms ${ }^{8}$. Due to the high case-fatality and difficulty in early diagnosis, prompt empirical treatment of suspected cases is recommended 9 .

Given its relevance, BSF is a disease of compulsory notification, currently regulated in Brazil by Ruling no. 104/2011 10. One detected case can mean the existence of an outbreak, which demands the immediate adoption of control mea- 
sures, and the case must be reported to all levels of government.

Surveillance of the disease aims mainly at early detection and treatment of cases, investigation and control of outbreaks, and description of cases according to their clinical and epidemiological characteristics 6. Minas Gerais reports cases of BSF yearly, and a major portion of the State's population lives in known risk areas for the disease. However, information is scarce on the current geographic distribution of the disease in the State, as well as on its case-fatality rate. Thus, the current study assesses the clinical and epidemiological characteristics of BSF cases in Minas Gerais from 2000 to 2008 with the aim of supporting surveillance of the disease in Minas Gerais and the bordering States, including São Paulo, Rio de Janeiro, Espírito Santo, Bahia, and Goiás.

\section{Methods}

This was a retrospective observational study using data collected from reporting forms in the Information System on Notifiable Diseases (SINAN) and epidemiological surveillance reports from the Minas Gerais State Health Department (SES/MG) and the Ezequiel Dias Foundation (FUNED). Confirmed cases reported from 2000 to 2008 were assessed according to the prevailing laboratory and clinical/epidemiological criteria for classification during the same period 6 . The data were consolidated through a standardized questionnaire for recording the following variables for each case: age, gender, date at onset of symptoms, municipality (county) where infection was probably acquired, confirmatory criterion (laboratory or clinical/epidemiological), and evolution.

For inclusion in the study, laboratory-confirmed cases were defined as patients with a clinical picture consistent with the disease and a positive laboratory test, as follows: (a) indirect immunofluorescence (in two samples, with at least a fourfold increase in titer); and/or (b) indirect immunofluorescence (single sample) with IgG titers $\geq 1$ :64 or any IgM titer; and/or (c) positive tissue immunochemistry for Rickettsia; and/ or (d) positive PCR; and/or (e) positive bacterial culture (and isolation).

Clinically/epidemiologically confirmed cases were defined as any case of death with a clinical picture consistent with BSF and a history of epidemiological antecedents.

The consolidated data were analyzed with SPSS, version 12.0 (SPSS Inc., Chicago, USA) and Epi Info, version 3.3.2 (Centers for Disease Con- trol and Prevention, Atlanta, USA). A descriptive analysis was performed including a description of the study population, frequency distributions, and measures of central tendency for the variables. We specifically evaluated the association between gender, age, presence of hemorrhagic manifestations, rash, and death. Difference between proportions was evaluated with the chisquare test. The magnitude of the association between the study variables and death was estimated by the odds ratio (OR) with a $95 \%$ confidence interval (95\%CI). Significance was set at 0.05 .

The study was submitted to and approved by the Institutional Review Board of FUNED (case number CAAE-0013.0.204.000-09).

\section{Results}

The study analyzed 132 cases of BSF in Minas Gerais State from 2000 to 2008 that met the criteria for confirmed cases. As for distribution by gender and age bracket, cases occurred predominantly in males ( $\mathrm{n}=104 ; 78.8 \%$ ), and median age was 26.5 years, ranging from 2 to 72 years (Table 1). There was a gradual increase in the number of cases detected over the study period, from 37 cases in 2000-2002 to 51 cases in 2006-2008. Rash was observed in half the cases (50.8\%) and hemorrhagic manifestations in $28.8 \%$ (Table 1 ).

The area with reported cases included $62 \mathrm{mu}$ nicipalities (counties) distributed across 7 of the 12 regions in Minas Gerais State (Figure 1). Greater Metropolitan Belo Horizonte, Rio Doce Valley, and Zona da Mata were the regions with the most confirmed cases, with $28.6 \%, 26.2 \%$, and $15.8 \%$ of the total cases, respectively. No cases were reported in the following regions of the State: Triângulo/Alto Parnaíba, Northwest, North, Central, and Campos das Vertentes. When the total numbers of BSF cases were assessed by month, there were confirmed cases every month of the year. However, the period from May to November included $88.6 \%$ of the total ( $\mathrm{n}=117$ cases), thus highlighting the marked seasonality of this disease (Figure 2).

Of the 132 cases analyzed, 53 evolved to death, representing an overall case-fatality rate of $40.2 \%$ (Table 1). Analysis of case-fatality by time period showed an increase from $32.4 \%$ in $2000-2002$ to $49 \%$ in 2006-2008 (Table 1). Presence of rash was associated with lower odds of death $(p=0.005)$ from BSF (Table 2). Presence of hemorrhagic manifestations showed a tendency towards association with death $(\mathrm{p}=0.064)$. Gender and age were not significantly associated with death.

From 2000 to 2008, cases were confirmed by the laboratory criterion in $69.7 \%$ of the series 
Clinical and epidemiological characteristics of patients with Brazilian spotted fever. Minas Gerais State, Brazil, 2000-2008.

\begin{tabular}{lcc}
\hline Characteristics & $\mathbf{n}(\mathbf{N}=132)$ & Frequency \\
& & $\%$ \\
\hline Gender & 104 & 78.8 \\
$\quad$ Male & 28 & 21.2 \\
$\quad$ Female & 132 & $26.5(2.0-72.0)^{\star *}$ \\
Age (years) & 67 & 50.8 \\
Rash & 38 & 28.8 \\
Hemorrhagic manifestations & & \\
Year of infection & 37 & 28.0 \\
2000-2002 & 44 & 33.3 \\
2003-2005 & 51 & 38.7 \\
2006-2008 & & 69.7 \\
Case confirmation criterion & 92 & 30.3 \\
Laboratory & 40 & 32.4 \\
Clinical/Epidemiological & & 36.4 \\
Case fatality & $12 / 37 * * *$ & 49.0 \\
2000-2002 & $16 / 44 * * *$ & 40.2 \\
2003-2005 & $25 / 51 * * *$ & \\
2006-2008 & $53 / 132 * * *$ & \\
Overall case fatality & & \\
\hline
\end{tabular}

* Median (range);

** The values in parentheses refer to the minimum and maximum ages, in years, for the cases analyzed in the article;

$\star \star \star$ Deaths/confirmed cases.

(92 cases) as compared to $30.3 \%$ (40 cases) by the clinical/epidemiological criterion (Table 1). Cases that evolved to death showed an increase in confirmation rate according to the laboratory criterion, from $8.3 \%$ in $2000-2002$ to $48 \%$ in 2006 2008 (Figure 3). There was also an increase in the proportion of confirmed cases according to the laboratory criterion, from $62.2 \%$ in $2000-2002$ to $74.5 \%$ in $2006-2008$ (Figure 3 ).

\section{Discussion}

This study showed an increase in the number of cases of BSF in the State of Minas Gerais, from 2000 to 2008, with apparent expansion in the transmission area, increase in case-fatality, and proportion of cases confirmed according to the laboratory criterion.

The increase in the number of confirmed cases was probably due to greater sensitivity in the epidemiological surveillance system, i.e., greater capacity to detect BSF cases. This finding is corroborated by the increase in the proportion of cases confirmed by laboratory testing. A possible explanation for this increase is that since 2002, Minas Gerais has used the Protocol for Hemorrhagic Fevers 11. Based on this protocol, a suspected sample for any condition in the group of acute hemorrhagic febrile syndromes (dengue, yellow fever, hepatitis, hantavirus, and leptospirosis) is also tested simultaneously for BSF. This system, which tests simultaneously regardless of the specific initial suspicion, differs from the previous system which only tested samples with direct suspicion of BSF. Therefore, this instrument may have increased the capacity to detect BSF cases in situations where the disease was not suspected initially.

In parallel with this expanded detection, there was an increase in the case-fatality rate, which may relate to improved diagnostic conclusion in deaths from suspected BSF. Cases of deaths that were previously concluded to be due to "ill-defined cause" or "indeterminate cause" began to be confirmed as deaths from BSF, based on the use of the Protocol for Hemorrhagic Fevers. An important observation that supports this hypothesis was the considerable increase in the proportion of deaths with the cause confirmed by the laboratory criterion, from $8.3 \%$ in 2000 2002 to $48 \%$ in $2006-2008$. 

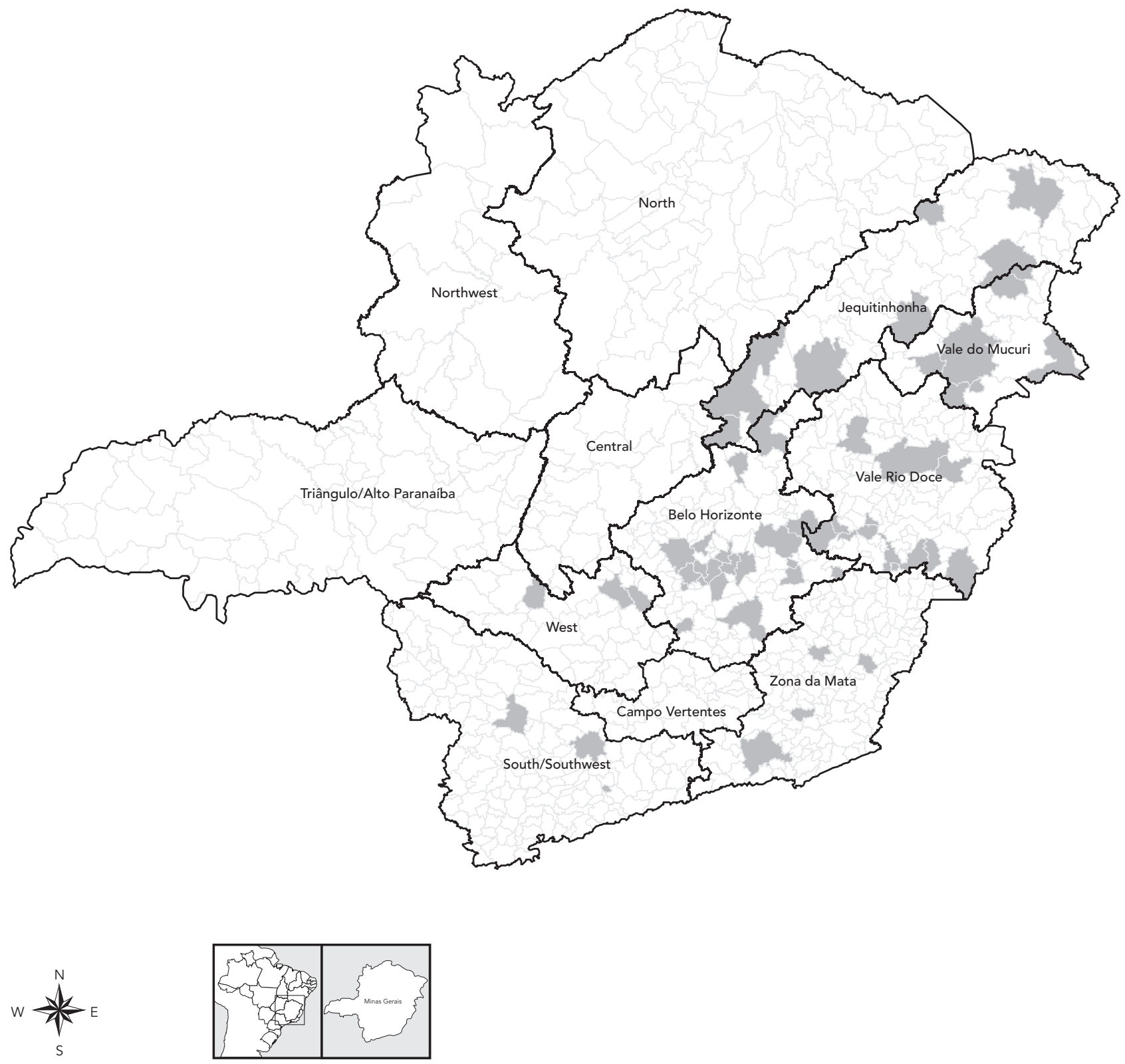

Note: areas in gray represent the municipalities (counties) with confirmed cases.

A previous study reported a $19 \%$ case-fatality rate for BSF in Minas Gerais 12 . The current study showed a case-fatality rate of $40.2 \%$. This rate is similar to that observed in the State of São Paulo 13, but higher than reported in other States of Brazil and for other rickettsial diseases in countries like the United States 1,13,14. In addition to improved conclusion of fatal cases, this high case-fatality rate in the State of Minas Gerais may also reflect health workers' difficulty in suspecting BSF. As suggested previously 15,16, other more common diseases like dengue and other febrile 
Risk factors for death from Brazilian spotted fever. Minas Gerais State, Brazil, 2000-2008.

\begin{tabular}{lccc}
\hline Characteristics & OR & $95 \% \mathrm{Cl}$ & p-value \\
\hline Male gender & 0.72 & $0.29-1.81$ & 0.447 \\
Age $\geq 27$ years & 1.47 & $0.68-3.17$ & 0.285 \\
Rash & 0.36 & $0.16-0.79$ & 0.005 \\
Hemorrhagic manifestations & 2.05 & $0.89-4.74$ & 0.064 \\
\hline
\end{tabular}

95\% Cl: 95\% confidence interval; OR: odds ratio.

\section{Figure 2}

Seasonal distribution of cases of Brazilian spotted fever. Minas Gerais State, Brazil, 2000-2008.

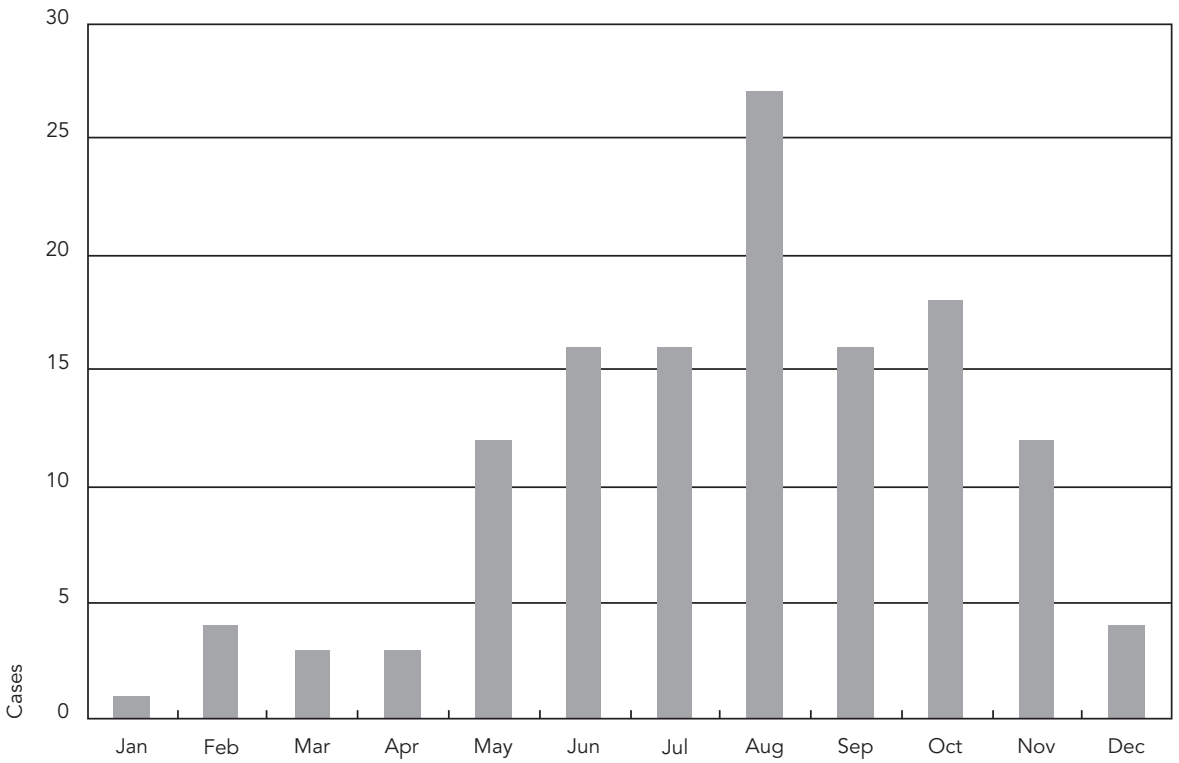

Note: The number of cases corresponds to the total observed during the period, distributed by month of occurrence.

exanthematic diseases show similar clinical characteristics and can cause confusion in the differential diagnosis. For the vast majority of these diseases, the recommended treatment does not require the use of antibiotics, or when it does, the antibiotics are not effective for treating BSF. It is thus difficult for physicians to initiate timely and effective treatment based only on clinical data.

Among the independent variables associated with the clinical outcome, the presence of rash was associated with lower odds of death. This finding confirms previous data showing that the presence of rash was associated with favorable evolution ${ }^{14}$. This probably results from greater diagnostic suspicion in cases with rash, favoring the early and adequate initiation of antibiotic treatment targeting BSF, a crucial factor for preventing death 4,17 .

This study confirmed the seasonal variation in the occurrence of BSF in Minas Gerais, with more cases from May to November, as described previously in the State of São Paulo ${ }^{12}$. The risk of BSF increases during this period of the year due to the greater presence of young forms (larvae and nymphs) of the Amblyomma cajennense tick, the principal vector for the disease. Since 
Percentage of deaths and total confirmed cases according to the laboratory criterion in three different periods. Minas Gerais State, Brazil, 2000-2008.

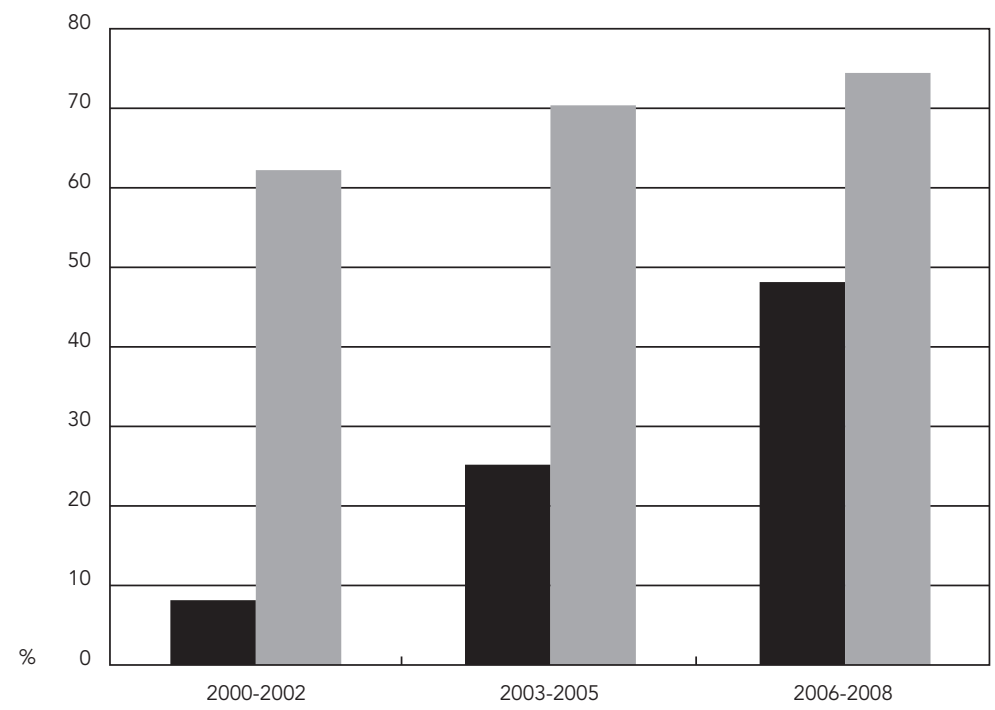

Percentage of deaths due to Brazilian spotted fever with diagnosis confirmed by the laboratory criterion

Percentage of total cases confirmed by thelaboratory criterion larvae and nymphs are smaller than adult ticks, people tend not to feel them, and they remain attached to the skin longer, thus increasing the risk of transmission 7 .

The stronger association with male gender and the median age of 26.5 years may result from this group's greater exposure to the tick, as suggested by a previous study in the State of São Paulo 13. However, this hypothesis could not be investigated in the current study, since these data were not available on the SINAN reporting forms for the entire study period.

The geographic distribution of BSF in the State of Minas Gerais proved to have expanded. In addition to the Mucuri, Jequitinhonha, and Rio Doce valleys, traditionally described as transmission areas in the State 6 , the Zona da Mata and Greater Metropolitan Belo Horizonte also proved to be epidemiologically relevant, since a significant proportion of cases occurred in these latter two regions. The South/Southeast and West of the State also entered the area with autochthonous BSF cases.

In 2009 there was a change in the definition for confirming and ruling out cases, according to guidelines from the Health Surveillance Secretariat 14 . According to the previous criterion, used for classifying cases until 2008, a single indirect immunofluorescence test with IgG titers equal to or greater than 64 or any IgM titer was sufficient to confirm the case. However, the new classification considers the results from more than one immunofluorescence reaction and includes the concept of "consistent case" for those with only one IIF with titers on the order of 64 . This new criterion requires adjusting the surveillance system to avoid losing the sensitivity acquired in recent years. Many cases that would have been confirmed by the previous criterion would now be defined as "consistent". This could lead to a reduction in the surveillance of BSF, due to the lack of confirmation of the pathogen's circulation in some areas. However, in order to prove this hypothesis it will be necessary to observe the trend in surveillance in the coming years.

The current study's results show BSF as one of the diseases with the highest case-fatality in the State of Minas Gerais. There is thus a real need to further consolidate epidemiological surveillance for early detection of cases and reduction of casefatality. This requires educational and preventive measures such as training health workers to detect and suspect cases, public awareness-raising campaigns on the disease, and action to contain proliferation of (and contact with) ticks. 


\section{Resumo}

A febre maculosa brasileira é a rickettsiose mais comum do território nacional, com maior importância nos estados de São Paulo e Minas Gerais. O objetivo deste estudo foi descrever os aspectos epidemiológicos dos casos de febre maculosa brasileira ocorridos em Minas Gerais no período de 2000 a 2008. Dos 132 casos confirmados, 53 evoluíram para óbito, representando uma letalidade de 40,2\%. O sexo masculino foi o mais acometido com 78,8\% dos casos confirmados, e mediana de idade de 26,5 anos. Entre os fatores de risco determinantes do óbito, a ausência de exantema apresentou associação significativa $(p=0,005)$. A Região Metropolitana de Belo Horizonte, o Vale do Rio Doce e a Zona da Mata responderam por 70,6\% dos casos, que ocorreram principalmente entre os meses de maio e novembro. Houve crescimento no número de casos, que apesar de sugerir expansão da doença, provavelmente decorreu do aumento da capacidade diagnóstica e sensibilidade do sistema de saúde. Apesar dessa melhora, a letalidade permaneceu alta e sem tendências à diminuição, o que implica a necessidade de medidas preventivas e assistenciais.

Febre Maculosa das Montanhas Rochosas; Infecções por Rickettsiaceae; Diagnóstico

\section{Contributors}

M. L. Ferraz and F. F. Amâncio participated in the study's conception and project, data analysis and interpretation, writing of the article, and approval of the final version for publication. V. D. Amorim, T. L. Chamone, M. G. Brito, S. B. Calic, A. C. Leite, and G. L. Fraga collaborated in the data analysis and interpretation, relevant critical revision of the intellectual content, and approval of the final version for publication.

\section{Acknowledgments}

The authors wish to thank Dr. José Eduardo Peçanha of the Belo Horizonte Municipal Health Department for his assistance in preparing Figure 1.

\section{References}

1. Del Fiol FS, Junqueira FM, Rocha MCP, Toledo MI, Barberato Filho S. A febre maculosa no Brasil. Rev Panam Salud Pública 2010; 27:461-6.

2. Cardoso LD, Freitas RN, Mafra CL, Neves CVB, Figueira FCB, Labruna MB, et al. Caracterização de Rickettsia spp. circulante em foco silencioso de febre maculosa brasileira no Município de Caratinga, Minas Gerais, Brasil. Cad Saúde Pública 2006; 22:495-501.

3. Galvão MAM, Calic SB, Chamone CB, Mafra CL, Cesarino Filho G, Olano JP, et al. Spotted fever rickettsiosis in Coronel Fabriciano, Estado de Minas Gerais. Rev Soc Bras Med Trop 2003; 36:479-81.

4. Galvão MAM, Dumler JS, Mafra CS, Calic SB, Chamone CB, Cesarino Filho G, et al. Fatal spotted fever rickettsiosis, Minas Gerais, Brazil. Emerg Infect Dis 2005; 11:265-70.
5. Galvão MAM, Lamounier JA, Bonomo E, Tropia MS, Rezende EG, Calic SB, et al. Rickettsioses emergentes e reemergentes numa região endêmica do Estado de Minas Gerais. Cad Saúde Pública 2002; 18:1593-7.

6. Secretaria de Vigilância em Saúde, Ministério da Saúde. Guia de vigilância epidemiológica. 6a Ed. Brasília: Ministério da Saúde; 2005.

7. Secretaria de Estado da Saúde de São Paulo. Varicela, difteria e febre maculosa brasileira: aspectos epidemiológicos no Estado de São Paulo. Rev Saúde Pública 2003; 37:817-20.

8. Dantas-Torres F. Rocky Mountain spotted fever. Lancet Infect Dis 2007; 7:724-32.

9. Chen LF, Sexton DJ. What's in new Rocky Mountain spotted fever? Infect Dis Clin N Am 2008; 22:415-32. 
10. Ministério da Saúde. Portaria $n^{\circ}$. 104. Define as terminologias adotadas em legislação nacional, conforme o disposto no Regulamento Sanitário Internacional 2005, a relação de doenças, agravos e eventos em saúde pública de notificação compulsória em todo o território nacional e estabelece fluxo, critérios, responsabilidades e atribuições aos profissionais e serviços de saúde. Diário Oficial da União 2011; 25 jan.

11. Secretaria de Estado de Saúde de Minas Gerais. Protocolo de febres hemorrágicas. Belo Horizonte: Secretaria de Estado de Saúde de Minas Gerais; 2002.

12. Galvão MAM. A febre maculosa em Minas Gerais: um estudo sobre a distribuição da doença no estado e seu comportamento em área de foco periurbano [PhD Dissertation]. Belo Horizonte: Universidade Federal de Minas Gerais; 1996.

13. Katz G, Neves VLFC, Angerami RN, Nascimento EMM, Colombo S. Situação epidemiológica e importância da febre maculosa no Estado de São Paulo. BEPA Boletim Epidemiológico Paulista 2009; 6:4-13.
14. Secretaria de Vigilância em Saúde, Ministério da Saúde. Guia de vigilância epidemiológica. 7ạ Ed. Brasília: Ministério da Saúde; 2009. (Caderno 12).

15. Galvão MAM, Silva LJ, Nascimento EMM, Calic SB, Sousa R, Bacellar F. Riquetsioses no Brasil e Portugal: ocorrência, distribuição e diagnóstico. Rev Saúde Pública 2005; 39:850-6.

16. Zavala-Velazquez JE, Yu X, Walker DH. Unrecognized spotted fever group rickettsiosis masquerading as dengue fever in Mexico. Am J Trop Med Hyg 1996; 55:157-9.

17. Costa PSG, Brigatte ME, Almeida EP, Valle LMC. Atypical fulminant Rickettsia rickettsii infection (Brazilian spotted fever) presenting as septic shock and adult respiratory distress syndrome. Braz J Infect Dis 2002; 6:91-6.

Submitted on $20 /$ Oct $/ 2010$

Final version resubmitted on 08/Apr/2011

Approved on 02/May/2011 